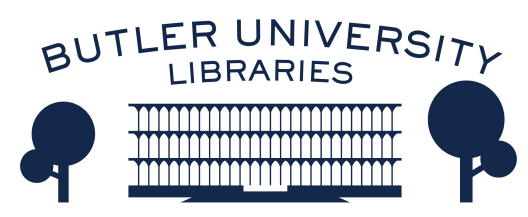

Journal of Hindu-Christian Studies

Volume 10

Article 15

January 1997

\title{
Book Review: "Jesus in Neo-Vedanta, A Meeting of Hinduism and Christianity"
}

Ronald Neufeldt

Follow this and additional works at: https://digitalcommons.butler.edu/jhcs

Part of the Religion Commons

\section{Recommended Citation}

Neufeldt, Ronald (1997) "Book Review: "Jesus in Neo-Vedanta, A Meeting of Hinduism and Christianity"," Journal of Hindu-Christian Studies: Vol. 10, Article 15.

Available at: https://doi.org/10.7825/2164-6279.1161

The Journal of Hindu-Christian Studies is a publication of the Society for Hindu-Christian Studies. The digital version is made available by Digital Commons @ Butler University. For questions about the Journal or the Society, please contact cbauman@butler.edu. For more information about Digital Commons @ Butler University, please contact digitalscholarship@butler.edu. 
of Songs, the Gospel according to John, Bonaventure's Journey of the Mind to God, the Spiritual exercises of St Ignatius Loyola, and Hans von Balthasar's Prayer, and invites the readers to enter into a project of reading back and forth between powerful texts across religious boundaries to gauge the possibilities and limits of personal commitments. For Clooney, the discourse of Bonaventure does not obliterate the discourse of the Srivaiṣnava ācārya Nampillai; adherence to the one does not preclude openness to the other (p.301). He clearly says that by reading these texts, with passion and intelligence, "the way one thinks about religious things is going to be transformed... The Bible, Bonaventure, Ignatius: for a Christian who has studied the Srivaisnava tradition, these are still there, still central, but they do not mean now what they did before" (p.304). When one studies texts like the Tiruvaymoli, one will probably be changed forever by it, but the gifts of such an enterprise can be enriching:

When...one allows one's eye to play across a series of juxtaposed Christian and Srivaisnava texts, all kinds of combinations become possible; if they are not immediately subjected to a rule of faith, the one text will be allowed to linger on the periphery of a credal commitment to the other. The reader will not forget Tiruvaymoli when reading the Bible, even if, as a Christian, one is totally committed to the Gospel. Or vice versa.

This kind of openness makes possible a wider and broader range of shifting positions, even for those who remain very much committed to their own traditions, if their commitments are strong enough that openness becomes interesting, and spiritually worthwhile (p.301). Clooney does not discuss what happens when one's commitment to one's tradition is not strong enough or when the transformation leads to the rejection of one's original commitment. While the author introduces his scholarly and religious affiliations in the opening chapter, the last chapter does not disclose much by way of the changes that are wrought in his life as a result of his commitment to the Tiruvaymoli. Rather, we are led through a thoughtful and rich series of possibilities that could occur with these boundary crossings.

Seeing through texts focuses on boundary crossings which lead one directly to the heart of another tradition. While this study focuses on texts, I was reminded of other boundary crossings which occur from the Hindu side by way of shared ritual. Many Hindus in South India make pilgrimages to the shrine of St Alphonsa or frequent the dargah (shrine where a Muslim saint is buried) of Shahul Hamid in Nagore. It would be a wonderful study if these boundary crossings share similarities with those that Clooney speaks about with such ardour and erudition.

This book is a very important contribution to the fields of Srivaișnavism, theology, and religious studies. It is a remarkable account of scholarship and passion, a "must read" book for all of us who dare to open and surrender ourselves to a text or ritual of another tradition, and appropriate it for ourselves.

Vasudha Narayanan

University of Florida

\section{Jesus in Neo-Vedānta, A Meeting of Hinduism and Christianity.} K. P. Aleaz. Delhi: Kant Publications, 1995, xiv +242pp.

AS THE TITLE indicates, the focus of this volume is on the treatment of Jesus in Neo-
Vedānta. The author confines Neo-Vedānta to Swami Vivekananda, Swami Akhilananda, 
Swami Prabhavananda, Swami Satprakashananda, Swami Ranganathananda, and Sarvepalli Radhakrishnan. In other words, with the exception of Radhakrishnan, the discussion focuses largely on the views of those swamis within the Ramakrishna Mission who were attracted to and offered commentary on the person and message of Jesus. The bulk of the volume (chapters four through ten) is in fact devoted to a summary presentation of this commentary. These presentations are preceded by discussions of the definition of Neo-Vedānta, the NeoVedāntic perspective on inter-religious relations and the importance of Neo-Vedānta for the construction of an Indian christology. The volume ends with brief discussions of various Indian Christian christological constructions, Christian responses to Vivekananda's views on aspects of Christianity, and the significance of NeoVedāntic christology.

The concern of the author is to present Neo-Vedāntic christology as an example or aspect of dialogical theology, which provides for mutual acceptance of religious faiths. In this case he is concerned about the possibility of the mutual convergence of Christianity and Hinduism. This, he argues, is possible only through pluralistic inclusivism, an approach in which one dares to receive insights from other traditions. The contributions thus received serve to fulfil the insights of one's own faith. Pluralistic inclusivism is juxtaposed against other theologies of religion; exclusivism, in which one sees one's own faith as the sole criterion for judgment; inclusivism, in which one sees the insights of other faiths as valuable, but insists that they must be fulfilled by the insights of one's own faith; and pluralism which sees traditions other than one's own as offering a legitimate path to salvation. The author sees Neo-Vedānta, particularly as enunciated by Vivekananda and Radhakrishnan, as pluralistic inclusivism. Hence his emphasis on these two thinkers and a few of the swamis of the Ramakrishna Mission.

The categories which the author uses to define the various theologies of religion are useful, particularly with respect to the discussion of Indian Christian constructions. They are less useful in the discussion of the Neo-Vedantins. For example, in the discussion of Radhakrishnan and Vivekananda, it is difficult to make a distinction between inclusivism and pluralistic inclusivism. There are obvious elements of "fulfilment theology" in the thought of both Radhakrishnan and Vivekananda which the author seems to ignore. It is true that one does not find sectarian emphases in either thinker. However, the mere absence of sectarian thinking is not reason enough to classify Neo-Vedantins as pluralistic inclusivists. There are in the thinking of Vivekananda in particular elements of exclusivism which need to be taken into account in any assessment of the usefulness of his thought in the enterprise of dialogue. Furthermore, both Vivekananda and Radhakrishnan do propose models of religion that are hierarchical in nature. This would seem to put them in the camp of inclusivism, as described by the author, rather than the camp of pluralistic inclusivism.

Why choose Neo-Vedānta in the first instance as fruitful ground on which to pursue the issue of convergence? The author argues that because our understanding is contextual any attempt at christology in India must take into account the Indian context and, in particular, the Indian ethos of pluralism. While he is no doubt correct in underlining the contextual nature of our understanding, placing Neo-Vedānta in a privileged position to speak about context and the Indian ethos of pluralism is a questionable exercise. This privileging is apparently based on the assumption that Advaita Vedānta is the culmination of human religious experience (p.8). NeoVedānta is, in turn, seen as a reconception of Advaita in which human history and human life are given an emphasis they do not have in Advaita. The author goes so far as to say that "the Indian hermeneutical 
context of Neo-Vedānta decides the content of the gospel in Jesus" (p.43). This is, in my view, a questionable approach to the context of Indian thought in that it perpetuates the myth begun in the early years of Indology that Advaita and modern reinterpretations thereof define all that is important in Indian and Hindu thought. Certainly recent scholarship on HinduChristian dialogue would challenge such privileging of Advaita and Neo-Vedānta in the context of Hindu thought. The author's description of the Indian ethos of pluralism must also be subjected to challenge. To argue that historically for the orthodox
Hindu any one dharma was not considered unique or superior seems to ignore the fundamental distinction between moksa dharma and other dharmas in classical Hindu thought.

Notwithstanding the issues raised above, the volume is a useful one for anyone interested in summaries of Neo-Vedāntic thinking on Christianity and the convergence or lack of convergence of this thinking with Indian Christian christological constructions.

Ronald Neufeldt University of Calgary

\section{Revelation, History, and the Dialogue of Religions: A Study of Bhartrhari and Bonaventure. David Carpenter. Maryknoll: Orbis, 1995, $\mathrm{xi}+20 \dot{8} \mathrm{pp}$.}

IN THIS BOOK David Carpenter undertakes a comparative study of the Indian grammarian and philosopher of language Bhartrhari (450-500 CE) and the Christian theologian Bonaventure (1221-1274), with a particular focus on revelation as exemplified in their respective scriptures, the Veda and the Gospel. Carpenter describes this project as an exercise in the history of religions and not in theology because, while he respects the importance of revelation and its truth for believers, he does not begin with any specific presupposition about how the truth of Veda or Gospel should impact the scholar's work. Rather, he is interested in determining what is meant by "revelation" and how it functions in these different religious systems. As a historian of religion, he wants to thematize revelation as an object of historical-critical scrutiny, examining "the diversity of disclosive or revelatory phenomena and the forms of their mediation" (p.5).

Carpenter pursues his inquiry through balanced and detailed considerations of Bhartrhari and Bonaventure. Bhartrhari is considered in the first part of the book, Bonaventure in the second, while the third part lays out points for comparison similarities and differences - and evaluates these points. Carpenter does a masterful job in chapters 2 and 3 in presenting Bhartrhari's difficult writings - grammatical and metaphysical statemenț are deeply intertwined - in a clear and accessible way. He helps us to understand Bhartrhari's deep consideration of Sanskrit, an analysis rooted in the language's grammatical details and in its larger role as reflective of a first Word original to the world, as the self-expression of the primal verbal reality, Śabda-Brahman. By comparison, the usually formidable Bonaventure seems rather accessible; chapters on his context (ch. 4), metaphysics of revelation (ch. 5), the history of revelation (ch. 6), and the reception of the language of revelation (ch.7) show us how rich and imaginative a thinker Bonaventure was, as a theoretician, practitioner, and preacher of the Christian faith, one who admirably intertwined the historical specificity of Jesus Christ with a larger 